\title{
Mathematics in Preschool and Problem Solving: Visualizing Abstraction of Balance
}

\author{
Mirella Forsberg Ahlcrona ${ }^{1}$, Ingrid Pramling Samuelsson ${ }^{2}$ \\ ${ }^{1}$ School of Health and Education, University of Skövde, Skövde, Sweden \\ ${ }^{2}$ Department of Education, Communication and Learning, University of Gothenburg, Gothenburg, Sweden \\ Email: mirella.forsberg.ahlcrona@his.se
}

Received 16 February 2014; revised 16 March 2014; accepted 23 March 2014

Copyright (C) 2014 by authors and Scientific Research Publishing Inc.

This work is licensed under the Creative Commons Attribution International License (CC BY). http://creativecommons.org/licenses/by/4.0/

(c) (i) Open Access

\section{Abstract}

This article describes how children learn to distinguish variations of the concept balance when they have different kinds of experiences of feeling, making and creating balance. The focus of the study is how children in preschool develop the ability to think logically and creative by exploring balance as phenomena in everyday life. Empirical data were collected in two preschool groups with children that were 3 - 5 years old. By following the process the results show that children and teachers increased their awareness and developed an understanding of balance, its meaning and significance, through creative teaching-by playing different games, drawing, constructing and building. The results also show that creative framework in performing activities seems to enrich the collective learning process as well as using mathematical concepts to describe the abstraction of balance.

\section{Keywords}

Creative Teaching, Balance, Problem Solving, Mathematics, Variation

\section{Introduction}

Robert Flughem (1989) said “All I need to know, I learnt in day-care”, and Ken Robinson (2006) (TED) among a number of others talked about early childhood education as a more creative learning environment than the later learning in school. Why is it like that? There may be many explanations, like young children have not grasped the codes of schooling yet, young children are more playful, or it may be that staff working with young children are closer to and interested in children as such, than later in school when the outcome in terms of subject takes 
over. It may also be a question if focus is more on the process in the early years and more on the results later. In whatever way it is, early childhood education is more creative and there is a larger openness and allowance for trying out new approaches (see e.g. Van Oers, 2012). This article will present an example of how creative communication between children and teacher, engage children in mathematical thinking and learning. The article also illuminates and discusses how the creative content in preschool affects and inspires children's using of mathematical operations to describe and explain the concept of balance. Initially, most of the teachers in this study perceived balance as something difficult and abstract, and wondered if it was a too advanced task for children. To explore content of balance by using innovative methods seemed as a challenging task and became the mutual scaffolding between children and the teachers.

The aim of this study is to explore and describe children's experiences of discovering balance and how they learn to use different strategies and ways of understanding abstractions. Further, the aim is also to investigate the communication process and how the teachers make children pay attention to and learn what happens when they have different kinds of experiences of feeling, making and creating balance.

\section{Theoretical Perspective}

The theoretical perspective used in this article and which also influenced the teacher's communication and interaction in the preschool setting, where the empirical data comes from, is called developmental pedagogy (Pramling Samuelsson \& Asplund Carlsson, 2008). This approach to early learning in preschool is based on numerous empirical studies carried out from a phenomenographic (Marton, 1981) perspective, that is, to find out children's taken for granted ways of thinking about the world that surrounds them.

The interpretations are based on children's actions (verbally and physically). From the research approach, where the idea is to give children space to express themselves widely, the research result become a discernment of various ways of thinking and talking as qualitative categories of conception that are possible to trace in a group of children (Pramling, 1983). From the phenomenographic research perspective and empirical studies, the preschool approach developmental pedagogy has been developed. The main characteristics are; to give children opportunities and possibilities to think, reflect and express themselves, but also to use children's various ways of thinking as a source for influencing their learning, that is, to add a metacognitive dimension into the communication between the teacher and the children (Pramling, 1990, 1996).

The idea behind this is closely related to creativity, as we here look upon it as a dimension in all learning where children create their meaning. This also means that children's perspectives become a key notion in learning (Sommer, Pramling Samuelson \& Hundeide, 2010). It is a question about possibility thinking (Langer, 1989), and allowing an "as if" dimension (Chappell \& Craft, 2011; Sawyer, 1997) into the communication. Learning is here defined as making sense of something (Vygotskij, 1995), which means that it is the process itself that is of interest in the pedagogy, as well as in the research.

Other dimensions that are of importance in young children's learning in preschool, and that are also taken into consideration in this approach are play, as well as using children's every day life and experiences as a base for communication. Although young children need to be active in concrete situations, the dimension of communication and interaction is necessary for children's learning to make sense of various aspects of the world around them.

\section{Mathematic in Preschool}

How to engage children in mathematical thinking and learning in early childhood, appear as an important and emerging research issue in preschool education (Björklund, 2010, 2012; Moomaw, 2011; Mulligan \& Mitchelmore, 2009; Sarama \& Clements, 2009). According to Reis (2011) the language of mathematics in preschool is present both in an informal and a formal way - mathematics is organized in living and children need to learn this order through different opportunities that vary from the formal mathematical concepts in the curriculum. One, among other tasks in this study, was that the teachers would acquire and use the mathematical language and concepts, and consistently use them while they communicate with children. The teachers' language was important for the children's ability to pay attention, understand and become aware of their own mathematical knowledge, actions and questions. That is, to become mathematical which means, creating new relationships with mathematics (Carruthers \& Worthington, 2011; Palmer, 2011). Mulligan (2011) argue that mathematics learning for all children can reach beyond basic numeracy and inspires pursuit of mathematical enquiry and creativity by involving children in modeling, drawing, representing and visualizing. 


\section{Method}

The empirical data was collected for two months by written observations, interviews, photographs and children's drawings. Two groups of children, age 3 to 5 years participated, each group with 20 children and 3 teachers. The starting point for the teachers work was to organize an approach based on an investigative and exploratory perspective. The study started with the concept of balance inspired by a letter from the witch Hildur asking the children for help to solve one, for her, very important problem. More specifically_her cat Anton had lost his balance and did not dare to move. Each of the teachers had, in their own group, the responsibility to explore balance from a certain perspective-construction games, didactic games or experiments. While working on different ways to investigate balance, the children were also encouraged to draw various suggestions on how the cat Anton would get his balance back.

Written observations means, that the teachers take notes of the children's spontaneous activities or discussions about balance that they notice during the day. Interviews were recorded once in a week and included several children participating at the same time, discussing questions about balance. All questions was based on written observations and asked with purpose to give children possibility of reasoning with each other. Photographs were used as a documentation of different ways of making and feeling balance-for example building large houses or holding a spoon with an egg on, in each hand, while walking in a different ways trying not to drop it on the floor. The children's drawings were mostly meant as an explanation for the cat Anton, how to practice and create balance. The teachers asked the children to describe, explain and talk about their drawings. Prasad (2008) and Wright (1991, 2003, 2010) describe drawing as a way of supporting children's way of thinking and as another way to concretize the abstract of the actual concept.

\section{The Empirical Section during the First Month}

A letter was read to the whole group:

Hello all children!

My name is Hildur. I am a witch that is extra short. I like to eat salmon and experimenting with different shapes. Right now I have a very big concern and I really hope that you can help me. My favorite cat Anton has lost his balance. He just lies down and does not dare to move. What should he do to get the balance back? I am very grateful for any suggestions and advice. Yours sincerely, Hildur.

The teachers that read the letter asked exploratory and open-ended questions to the children. For example, what do we know about the balance? What is it that we do not know? How can we find out more about the balance to help Anton the cat? How do we know that we have the balance? When is it needed? Meanwhile another teacher wrote/recorded how the children reasoned, and what suggestions they had. In the light of what has emerged from the children's responses, it was decided in which direction the balance would begin to explorebased on the children's own proposals, through didactic games, construction games or experiments. During the month children were photographed when they balanced in different ways and with different objects. Their building constructions were photographed too-when some of them collapsed, the children discussed possible weaknesses, like the lack of balance being the reason. The children were encouraged to develop different strategies and approaches by various games and activities, discuss each other's experiences and thoughts about the balance, in order to find possible solutions. At the end of the month the letter was read again and the children's responses, as a letter with suggestions and some good advice included, as well as the children's drawings for the cat, was sent to the witch. On that occasion the teacher discussed with the children the difference in their very first comment about balance compared to the last comments, and how this difference could be explained.

\section{The Empirical Section during the Second Month}

The new letter came from the witch as a response to the children's suggestions and advice. This time she wanted more specific help:

Hello all helpful and creative children!

Thank you for the all interesting and exciting thoughts about balance. And thank you kindly for all the good advice, suggestions and ways to help Anton to practice balance and once again become my old mischievous cat. You said that I can charm back the balance, but the truth is that I belong to a family of extra-short witches, and we don't have enough power to cast spells. I'm only 50 centimeters long. So I wonder: where will Anton get 
space for everything you wrote about? My cave is not big enough and it cannot hold all boards, ropes, branches, bricks, bicycles, bean bags and other things that you are saying that he needs to work on balance. He needs a hut where he can do all those exciting things that you suggest. Hope you can give some suggestions for such a hut. Send photos of different models of a balance hut, and explain what and how Anton can do there. Until then, I'll keep Anton and give my support so that he begins to stand on his legs-just the way you wrote. I'll also sharpen his claws so he can get a good grip. You wrote that he should keep his legs out and practice balance. I do not understand what you mean, because then he falls on his tummy! If you draw what you mean, then I'll probably understand much better. We long for your replies, Anton and I. Yours sincerely, Hildur

This time the task for the children was to build a balance hut for Anton and use various strategies in order to reflect on their mathematical knowledge and actions. The work about balance continued in another directionthrough creating things, conversations about their own world, problem solving, and various activities in small groups. The focus was on making the children's understanding of balance wider. First, by drawing a sketch/ model of the hut and secondly, by building the hut based on different suggestions. The questions that whole group had to discuss and decide before the work began was: what balances should Anton be able to practice in the hut? What will the hut look like? What materials can be used for the hut? Now was the time to put their past experience and knowledge of the balance into practice, to another dimension by constructing and building. Children's proposals, with various sketches, were featured as an exhibition. They discussed each other's sketches and three smaller groups were formed — they made their own sketch and built a model of the hut. What would be inside the balance hut?

This question was answered on the basis of the children's knowledge of the outside world, where what applies to humans, also was applied for the cat. Those of the children, who knew someone that was into training, came with detailed information about what Anton could possibly need in his hut. Many children got inspiration from various TV-sport shows. The children had many different suggestions. It could be bicycle, balance sheet, weightlifting, skateboarding, balance rope, running track and rings, trampoline, etc. It was also important to have food and something to drink. For a bit of relaxation a TV and a bed to sleep in, was also needed. Spotlights were also important because Anton also trained at night time. Each teacher followed her group and documented the children's work through notes, interviews and photographs. At the end of the month all teachers did an individual evaluation based on the documentation and their own reflection about the working process with the balance.

\section{Results}

The analysis shows that children discovered variation of the balance presence in everyday life by identifying it in a conscious way as expression of social experience and as different mathematical operation. Both teacher and the children have been practicing their creativity through problem solving and experience-sharing with others in the group. Through conversation, participation and the common reflection, children got experienced balance as a meaning and purpose in preschool, but also as ability and a skill. The discussion was often about who has done what in smaller groups, on the balance, and so intertwined children's individual experiences to the group's common knowledge. Communicative process through the group activities served as a knowledge arena where children and teachers discussed the group's tasks, strategies and results.

\subsection{Balance as an Expression of Children's Social Experiences}

An example of how the children perceived the balance related to a social event is that if someone drives a motorcycle and has bad balance, then an accident might happen. Then you need an ambulance and perhaps many doctors and the family will be sad because the one driving the motorcycle had bad balance. Another example of balance related to a social experience is one of the letters to Hildur, which indirectly illustrates children's own experience of practicing and exploring the meaning of balance. The letter can also be seen as children's common knowledge about balance where each individual contributes in its own way.

Hi Hildur!

Here are suggestions and instructions from the children of the Bear-group, on how Anton can get his balance back.

- He can practice so he gets his balance back by walking on a wooden board and use his claws to get a better 
grip when he is walking.

- If he is crawling under the tunnel one can get a better balance.

- Stand next to him and hold him so he can practice.

- It is good to hold two equally heavy things because then you can't lose your balance.

- He has to put one foot in front and then the other and then put them behind him when he is walking.

- He has to practice many times so he is walking straight, not on the side nor lean over.

- He has to train his head to get smarter. He has to think.

- He can balance on a rope.

- Practice and walk on a wooden board so he gets steady.

According to the teacher's observations and reflections, it became obvious that the children developed a broader view of balance as a concept. "When we read the letter the first time, the children talked most about the balance as standing on one leg. After the different construction and building activities, they were more reflections on such things as evidence and how the materials were formed. They were also aware of that they can help each other to maintain balance. Although, you need to concentrate and not be in a hurry when you balancewhether it involved the body or something you built. Someone said that the cat must think as he tried to keep his balance." When the teachers and the children discussed their responses to the witch and read what they answered the first time, they noticed how different the answers were in the end of the month—more children were aware of what balance means and actually is, and could give examples on how to train it. When the children discussed how to help Anton to get his balance back, they had several interesting suggestions: give the cat some water, Hildur can pretend to be a cat and take the lead and show the balance or let the cat move after the breakfast so he can get a new balance. According to the teachers, what the children know and understand about balance, depends on the ways they have experienced it and explored it as a phenomena in everyday life.

\subsection{Balance as Mathematical Problem Solving Operation}

Many of the children wondered what Hildur looked like, so in her second letter she sent a photograph of herself. Most of the children were surprised that she was so small and short, because they thought that she was like an adult. But then, how long is Anton? Most of children thought that Anton was the same size as a normal cat-in relation to the witch, initially perceived as big as an adult. When faced with quite an unusual problem, the children and the teachers conversed and collaborated in a different ways than before. Estimating the cat's size in relation to the witch, and then adjust it to the size of the hut was no easy task. Solving the problem created different strategies and concrete mathematical experiences-for example, to measure all children and adults in the group and attach stripes of fabric on the wall, and then discuss the different sizes/proportions when it comes to their clothes, shoes and furniture. In one group some of the children's newborn siblings were also measured and contributed with their length, but it was clear that Hildur was the shortest.

"We talked about how big Anton could possibly be: $5 \mathrm{~cm}$, said one child. A witch cat is no ordinary big cat, but if the witch is so tall the cat still has to be less, otherwise she cannot take care of it. The cat cannot reach up to the witch's waist! We discussed and measured, and agreed on that Anton is probably about $10 \mathrm{~cm}$ high."

"One child also said that a cat is shorter than a man. That means Anton must be much shorter than Hildur. So then we started counting again and came to the conclusion that Anton was probably $20 \mathrm{~cm}$. Then the very same child said that his cat is very thick, and certainly as big as Hildur. He would ask his mother to bring a picture that he could show us."

The teachers describe how the task and knowledge of balance linked both to the spontaneously arising situations in everyday life, as well as to different routine situations. Children's involvement also involved parents through the documentation presented continuously, but also from an increasing interest in balance that the children showed outside the preschool.

\section{Discussion}

Education is according to Vygotsky (1986) an opportunity to create new forms of thinking through the social organization of teaching in which the relationship between teacher and child, involves a specific form of cooperation. The dialogue between the child and the teacher creates experiences, language and thinking which challenges the child's "zone of proximal development" - a concept that Vygotsky (1978), launched as part of the attempt to explain how the process of cooperation could contribute to children's systematic knowledge. The 
physical explanation of the balance dominated the first week-the balance was something you found or lost. Through various didactic games and creative activities, other mathematical concepts and skills were, besides the balance, deepened and widened. For example, one teacher wrote the following: "When we would start building a model of the balance hut, I first had to explain what a model was because no one in this group knew it." In their reflections, the teachers also expressed an increasing need to develop their own communication skills and working methods. For example, to get better at asking questions or the significance of varying the content to motivate children's learning. "I'm discovering more and more that I need to practice how to ask questions and follow up questions, to find out how children think and make them more curious. I also understand now considering the tasks we have done, how important it is that teachers can organize learning situations and problematize how to inspire and awake new thoughts for children when it comes to math.” To learn and be able to create something, means that the teacher consciously broadens children's knowledge and enables for children to pay attention to, understand and become aware of their knowledge and actions. In practice this means that what children are expected to create an understanding of, must also be made visible to them in many different ways (Doveborg \& Pramling Samuelsson, 2012; Duffy, 2006; Magnusson, 2013; Smidt, 2010).

According to the teachers in the study, there were no children who questioned the letter's credibility or the witch's existence. The focus was directed entirely towards helping the cat Anton. In the witch's letter where she appeals for help for her cat, contributed to the development of children's "inner theater" that refers to the ability to switch between the actual and fictional realities (Bernier \& O'Hare, 2005; Hamre, 2004; Harris, 2000; Tyrrell, 2001). The witch Hildur is a glove puppet and that was obvious on the photograph in her second letter. Use of the puppet as a tool in communicating with children involves different forms of interaction (Forsberg Ahlcrona, 2009, 2012, 2012a). In the work on balance, it was not supposed to make use of a puppet in direct communication with the children but that the letter would belong to a witch was an intentional choice, according to the previous experience of the witch Hildur and her involvement in preschool (Forsberg Ahlcrona, 2012b). Why the witch and not someone else? A simple answer is that the witches as a cultural phenomenon, already exists in a different ways in most children's imagination. Children's perceptions and knowledge of witches comes from literature, stories and films. Children know that witches can have powers that ordinary people do not have and that they can also be different as person, as people. A witch's world, offer an invitation to play with many possibilities and unexpected events—like "as if" ... "we pretend that" ... and "anything can happen in the witch's world” (Craft, 2002; Hendy \& Toon, 2001). According to Vygotskij (1995), this ability is an important prerequisite for the child's imagination and creativity development. He argues that it is about the constant exchange between experience level and dissimulation level, where language and communication are essential (Hoff, 2003; Sawyer et al., 2003). By making use of a fictitious person as a witch, the children's own perceptions of the witch in combination with teachers planned content, contributed to the development of subjective learning environments that children were inspired and motivated to interact with. In working with the balance, witch Hildur functions as a starting point and a content of the common communication—children and teachers spoke about her and did things because of her. According to Vygotskij (1995) the imaginary creative activity directly depends on the richness and diversity of human experiences, as these constitute the material that imagination are built of. And imagination can result in creative acts, according to Vygotskij. In psychology termed imagination as a form of consciousness, an imagination associated with reality. Thus, the well-known expression "it's only imagination that sets the limits" reinterpreted it is the reality that limits the imagination.

\section{Conclusion}

According to the teacher's evaluation, both children and the teacher participate equally on creating new mathematical content in preschool and developed conceptual world and knowledge, about balance. Yet, in different ways-children were found to be curious and proactive in their learning, focused and willing to experiment while the teacher's own commitment affects the organization of teaching and motivates the creation of new activities. As it was mentioned earlier, initially most of the teachers in this study perceived balance as something difficult and abstract, and wondered if it was a task too advanced for children. That was because they had never worked with the concept of balance before. To conclude, education in preschool as a creative process presumes, for the children, more explorative and imaginary contents, and for the teachers, challenging educational concepts, teaching aids and methods. 


\section{References}

Bernier, M., \& O’Hare, J. (2005). Puppetry in Education and Therapy: Unlocking Doors to the Mind and Heart. Bloomington, IN: Authorhouse.

Björklund, C. (2010). Broadening the Horizon: Toddlers' Strategies for Learning Mathematics. International Journal of Early Years Education, 18, 71-84. http://dx.doi.org/10.1080/09669761003661246

Björklund, C. (2012). What Counts When Working with Mathematics in a Toddler-Group? Early Years, 32, 215-228. http://dx.doi.org/10.1080/09575146.2011.652940

Carruthers, E., \& Worthington, M. (2011) Understanding Children's Mathematical Graphics. Beginnings in Play. Maidenhead: Open University Press.

Chappell, K. A., \& Craft, A. R. (2011). Creative Learning Conversations: Producing Living Dialogic Spaces. Educational Research, 53, 363-385. http://dx.doi.org/10.1080/00131881.2011.598663

Craft, A. (2002).Creativity and Early Years Education: A Lifewide Foundation. Continuum Studies in Lifelong Learning, London: Continuum.

Doveborg, E., \& Pramling Samuelsson, I. (2012). Att förstå barns tankar-Kommunikationens betydelse [To Understand Children's Thinking —The Importance of Communication]. Stockholm: Liber.

Duffy, B. (2006). Supporting Creativity and Imagination in the Early Years. Maidenhead: Open University Press.

Flughem. R. (1989). Allt jag behöver veta lärade jag mig på dagis [All I Need to Know I Learnt in Day-Care]. Stockholm: Bonniers.

Forsberg Ahlcrona, M. (2009). Handdockans kommunikativa potential som medierande redskap i förskolan [The Puppet’s Communicative Potential as a Mediating Tool in Preschool]. Göteborg: Acta Universitatis Gothoburgensis.

Forsberg Ahlcrona, M. (2012). Förskolans didaktik och dockan som redskap-Kommunikation och skapande i förskolan [Preschool Didactic and Puppet as a Tool_Communication and Creation in Preschool]. Lund: Studentlitteratur.

Forsberg Ahlcrona, M. (2012a). The Puppet's Communicative Potential as a Mediating Tool in Preschool Education. International Journal of Early Childhood, 44, 171-184. http://dx.doi.org/10.1007/s13158-012-0060-3

Forsberg Ahlcrona, M. (2012b). Handdockan i pedagogiken. Vad handlar det om? [Puppets in pedagogy. What is it about?]. In A. Klerfelt, \& B. Qvarsell (Eds.), Kultur, estetik och barns rätt i pedagogiken (pp. 181-196). Malmö: Gleerups.

Hamre, I. (2004). Learning through Animation Theatre. Prague: UNIMA.

Harris, P. L. (2000). The Work of the Imagination. Understanding Children's Worlds. Oxford: Blackwell Publishers.

Hendy, L. \&Toon, L. (2001).Supporting Drama and Imaginative Play in the Early Years. Buckingham: Open University.

Hoff, E. (2003). The Creative World of Middle Childhood. Creativity, Imagination, and Self-Image from Qualitative and Quantitative Perspectives. Lund: Lund University.

Langer, E. (1989). Mindfullness. Cambridge, MA: Persens Books.

Magnusson, M. (2013). Skylta med kunskap: En studie av hur barn urskiljer grafiska symboler i hem och förskola [Signing with Knowledge: A Study of How Children Discern Graphical Symbols at Home and in Preschool]. Göteborg: Acta Universitatis Gothenburgensis

Marton, F. (1981). Phenomenography—Describing Conceptions of the World around Us. Instructional Science, 10, $177-200$. http://dx.doi.org/10.1007/BF00132516

Moomaw, S. (2011). Teaching Mathematics in Early Childhood. Baltimore, ML: Paul Brookes.

Mulligan, J. T., \& Mitchelmore, M. C. (2009). Awereness of Pattern and Structure in Early Mathematical Development. Mathematics Education Research Journal, 21, 33-49.

Mulligan, J. T. (2011). Towards Understanding of the Origins of Children's Difficulties in Mathematics Learning. Austrralian Journal of learning Difficulties, 16, 19-39.

Palmer, A. (2011) Hur blir man matematisk? Att skapa nya relationer till matematik och genus $i$ arbetet med yngre barn [How to Become a Mathematical? Creating New Relationships to Mathematics and Gender in Work with Younger Children]. Stockholm: Liber.

Pramling Samuelsson, I., \& Asplund Carlsson, M. (2008). The Playing Learning Child: Towards a Pedagogy of Early Childhood. Scandinavian Journal of Educational Research, 52, 623-641. http://dx.doi.org/10.1080/00313830802497265

Pramling, I. (1983). The Child's Conception of Learning. Göteborg: Acta Universitatis Gothoburgensis.

Pramling, I. (1996). Understanding and Empowering the Child as a Learner. In D. Olson, \& N. Torrance (Eds.), Handbook of Education and Human Development: New Models of Learning, Teaching and Schooling (pp. 565-589). Oxford: Basil 
Blackwell.

Pramling, I. (1990). Learning to Learn. A Study of Swedish Preschool Children. New York: Springer Verlag. http://dx.doi.org/10.1007/978-1-4612-3318-3

Pramling, I. (1994). Kunnandets grunder. Prövning av en fenomenografisk ansats till att utveckla barns förståelse för sin omvärld [The Foundations of Knowing. Test of a Phenomenographic Effort to Develop Children's Ways of Understanding the Surrounding World]. Göteborg: Acta Universitatis Gothoburgensis.

Prasad, S. (2008) Creative Expressions: Say It with Art. Chennai, India.

Reis, M. (2011). Att ordna från ordning till ordning. Yngreförskolebarnsmatematiserande [To Order, from Order to Order: Toddlers' Mathematizing]. Göteborg: Acta Universitatis Gothenburgensis.

Robinson, K. (2006) How Schools Kill Creativity. http://www.ted.com/talks/ken_robinson_says_schools_kill_creativity.html

Sarama, J., \& Clements, D. H. (2009). Early Childhood Mathematics Education Research Learning Trajectories for Young Children. New York: Routledge.

Sawyer, R. K. (1997). Pretend Play as Improvisation. Conversation in the Preschool Classroom. Mahwok, NJ: Erlbaum.

Sawyer, R. K., Moran, S., John-Steiner, V., Sternberg, R. J., Feldman, D. H., Gardner, H., Nakamura, J., \& Csikszentmihalyi, M. (2003). Creativity and Development. Oxford: University Press. http://dx.doi.org/10.1093/acprof:oso/9780195149005.001.0001

Smidt, S. (2010). Vygotskijoch de små och yngre barnens lärande [Vygotsky and Early Years Education]. Lund: Studentlitteratur.

Sommer, D., Pramling, S. I., \& Hundeide, K. (2010). Child Perspectives and Children's Perspectives in Theory and Practice. New York: Springer. http://dx.doi.org/10.1007/978-90-481-3316-1

Tyrrell, J. (2001). The Power of Fantasy in Early Learning. New York: Routledge.

Van Oers, B. (2012). Developmental Education for Young Children. Concept, Practice and Implementation. Dordrecht: Springer.

Vygotskij, L. S. (1995). Fantasi och kreativitet i barndomen [Fantasy and Creativity in Childhood]. Göteborg: Daidalos.

Vygotsky, L. S. (1978). Mind in Society: The Development of Higher Psychological Processes. Cambridge, MA: Harvard University Press.

Vygotsky, L. S. (1986). Thought and language. Cambridge, MA: MIT Press.

Wright, S. (1991). The Arts in Early Childhood. Upper Saddle River, NJ: Prentice Hall.

Wright, S. (2003). Children, Meaning-Making and the Arts. Melbourne: Pearson Education.

Wright, S. (2010). Understanding Creativity in Early Childhood. Meaning-Making and Children's Drawing. Thousand Oaks, CA: SAGE Publications Ltd. 